apart only by the interposed rolling pin, cause it to revolve, and the angle through which it has moved can then be read off with the help of the pointer and dial. The best results have been obtained with a wire which was drawn, and which measures exactly or 5 inch in circumference. The dial is divided into fifteen equal parts, and their decimals, so that one division represents onethousandth of an inch, and variations as small as a twentythousandth of an inch can be detected.

The above instrument is the outcome of another instrument invented by Mr. Stromeyer, of still greater sensitiveness, and which is based on the production of Newton's rings. Its extreme sensitiveness and certain practical difficulties, however, make it unsuitable for the use of the engineer or naval architect, to whom the present instrument is of great value, and by whom it can be very conveniently used.

The strains of a ship in a sea-way have always been very difficult to deal with. Agur and Solomon of old frankly admitted they were "too wonderful" for them, and although the same ingenuousness has not always been practised by naval architects since, the fact remains that the present state of knowledge in this subject is extremely meagre. Methods of calculation have, it is true, been in use by naval architects which have given results most useful for comparative purposes, but which in absolute units frequently indicated forces that ships could not bear. These methods therefore, except for the comparative purposes they were primarily designed to serve, threw no light whatever on the actual conditions of stress on the various parts of the structure in a sea-way. One able investigator showed that the dynamic constitution of sea-waves was such as to make the effective variation of buoyancy enormously less than the apparent variation, and that this difference meant a reduced variation of stress in large ships from, in some cases, I70 to Ioo. This investigation cleared up many pre-existing difficulties. Mr. Stromeyer, however, by means of his beautiful and simple apparatus, enables the variation of stress on any part of any structure, ship, or anything else under the action of any forces to be arrived at with certainty by direct experiment.

The invention of this little apparatus constitutes an era in the science of the strength of complicated structures such as ships, boilers, \&c.

\section{WILLIAM BABCOCK HAZEN}

THE sudden death of Brigadier-General William $B$. Hazen, Chief Signal Officer of the United States Army, which occurred on Sunday, January I6, I887, deprived the country of one of its most distinguished officers, and the Signal Corps of a chief who took a broad view of its duties and relations to the world of business and science.

General William B. Hazen was the great-grandson of Thomas Hazen, who was born I7I9. Thomas Hazen was himself great-grandson of Edward Hazen, who emigrated from England before 1649, and settled at Rowley, Mass., where he died in 1683.

The descendants of Edward Hazen include many names eminent in business, theology, and war: energy, industry, and strong convictions characterise the members of the family on all sides.

General Hazen was born at West Hartford, Vermont, September 27, I830. While he was a child his parents removed to Hiram, Portage County, Ohio. In $185 \mathrm{I}$ he was appointed from Ohio as a cadet to the United States Military Academy, at West Point, from which he graduated on July I, I 885 . He was assigned to the 8th U.S. Infantry, and spent the next five years in frontier service, more especially against the Indians in California, Oregon, and Texas, in which service he displayed an energy and bravery that have been characteristic of his life. His record during these years embraces constant fights and pursuits. He was twice severely wounded, and by virtue of the latter be was, in January I 860 , by the surgeon's order, granted a leave of absence as being unfit for duty. In consequence of this he was at the north while his regiment was in Texas at the breaking out of the Rebellion. The regiment having been captured and its officers released on parole, he alone was unembarrassed by the parole and was able to offer his services to the Union Army ; he was at once assigned as temporary instructor at West Point. In May I86I, he became captain of the 8th Infantry of the regular army, and in October was made colonel of the 4Ist Regiment of Ohio Infantry in the volunteer army. During the war he distinguished himself on many occasions, and his commission as majorgeneral was granted him December 13, I864, for "specific distinguished services," i.e. "for long and continued services of the highest character, and for special gallantry and service at Fort McAllister." This placed him fifth in a list of twenty-four officers who had received commissions for distinguished service.

$\mathrm{He}$ continued serving on the frontier territories north and west, and was especially active in Indian affairs until I 870, in which year he was allowed leave of absence to visit the seat of war in Europe. The results of his observations and studies during his six months' absence are embraced in a volume entitled "The School and the Army in Germany and France, with a Diary of Siege Life at Versailles" (New York, I872). This volume contains a very interesting sketch of Bismarck, and an account of the state of affairs in Europe. It contains especially a fair criticism of the relative excellencies of the German and French systems, both civil and military; in a special chapter on that subject he incidentally brought out more prominently some weak points in our own military organisation. It would seem that the courage displayed so brilliantly on the battle-field frequently nerved him to utter not only these but other fearless criticisms of things that were palpably wrong, and some of which have since been corrected.

He was married, February I 5, I87 I, to Millie, daughter of the Hon. Washington McLean, of Cincinnati, who, with one son, survives him.

On his return from Europe in $187 \mathrm{I}$, he returned to duty in the Indian Territory, and was with his regiment in Kansas and Dakota, except for a short absence, until December I 5, I880, when he was, by President Hayes, appointed Brigadier-General and Chief Signal Officer, and has since then been stationed at Washington. The absence just referred to was occasioned by his again visiting Europe as Military Attaché to the United States Legation at Vienna, for the purpose of studying the operations of European armies during the Turko-Russian War. He was absent on this service from December 1876 to June 1877 , and the results of his observations were published subsequently in a highly interesting popular volume.

The general account of his activity during the war of the Rebellion was published by him in his "Narrative of Military Service" (Boston, I885).

His letters and pamphlets on the "Bad Lands" show that for many years General Hazen had been studying the relations of meteorology and agriculture. After his appointment as Chief Signal Officer, he was indefatigable in his efforts to improve the military and departmental relations of the Signal Service, its scientific character, its practical usefulness to farmers and herders, and its popular influence. His labours in Washington stirred up most virulent opponents, first when it became necessary for him to expose and prosecute the corruption of Capt. Howgate; again, when it became necessary in self-defence to expose the true reasons of the failure of the War Department to properly support and 
succour the Signal Service Expedition to Fort Conger; and again, when he had occasion to defend the advantages of the military character of the combined Signal Service and Weather Bureau organisation against those who would take it from the army without making a proper provision for its work in any other Department. The records of his successful defence against attacks prompted by implacable hate, official stubbornness, and personal ignorance, are to be found in the proceedings of "CourtsMartial," "Courts of Inquiry," "Committee of Congress on Expenditure," and especially in the "Testimony before the Joint Commission to consider the present organisation of the Signal Service," \&c., which latter voluminous report and testimony was presented in June 1886.

General Hazen's interest in meteorology, as before said, properly dated back earlier than I873, at which time he prepared a letter "On our Barren Lands, or the interior of the United States, West of the Iooth Meridian, and East of the Sierra Nevadas." This was published in the New York Tribune, February 27, I874, and led to a discussion in that paper and in the Minneapolis Tribune between himself and General A. A. Custer, which is summarised in a pamphlet of the above title, published by Robert Clarke and Co., of Cincinnati, in 1875 . The motive of General Hazen evidently was the protection of investors and settlers against the too glowing accounts, which amounted to virtual misrepresentation on the part of the employés of the Northern Pacific Railroad. His compilation of climatological data, and his statement of personal experience baserl on long residence in that region, largely contributed to prevent blind emigration into an inhospitable country, while they doubtless also contributed to direct attention to the really valuable portions of our north-west territory, so that the permanent development of that portion of the United States has been furthered by his action. It was, however, at the time, on his part a very characteristic outspoken exposition of what seemed to him a fraud and imposition perpetrated by unscrupulous financiers upon foreign immigrants and over-confiding settlers and investors.

During his connexion with the Signal Office, General Hazen frequently took occasion to show his appreciation of the fact that the weather predictions were essentially not a matter of mere military routine, but that in all its details the office had need of the work of specially trained experts, that it was a mistake to shut one's eyes to the fact that, in a matter of applied science like this, some of those whom the scientific world recognises as meteorologists and physicists must be employed, and be required to keep the chief fully informed of the progress of science. Perhaps this is best exemplified by a quotation from his letter of March 24, I886, addressed to a Committee of the House on Expenditures of the War Department:- "At the beginning of the work of the Signal Service the duty of giving notice of the approach and force of storms and floods for the benefit of commerce and agriculture throughout the United States implied that the notices should be correct, reliable, and timely, as none others could possibly be of benefit; it was therefore absolutely necessary to provide for the careful study of the atmosphere. On my accession I found every evidence from popular criticism that still further progress in weather predictions was expected. I therefore emphasised especially the necessity of the study of the instruments and methods of observing, and the investigation of the laws of the changes going on in the atmosphere. .... It is evident by these successive steps that in addition to knowledge gained for current work the office is powerfully contributing towards the establishment of a deductive science of meteorology which will eventually give us a solid, rational basis for predictions, thereby improving on the empirical rules by which predictions have generally been made hitherto." And he adds that he was led more especially to assist in the researches on the sun's heat by reason of the encouragement given him by the late President Garfield, whose "last words to me were, "Give both bands of fellowship and aid to scientific men.'"

As a further illustration of General Hazen's appreciation of the scientific needs of the office must be noted his appointment of Prof. William Ferrel as meteorologist, and of Prof. T. C. Mendenhall as electrician. To the latter, all matters relating to standards, instruments, and instrumental research were also committed. Nor did General Hazen stop here; by appointing several younger men to positions as junior professors he largely increased the amount of study and research that the office was able to perform, and by publishing a series of professional papers and smaller notes, he took the final steps necessary to stimulate every man to do his best.

Labouring in this same direction, he sought to elevate the intelligence and scientific training of the Signal Corps proper by enlisting College graduates as far as possible, by extending the course of instruction for observers, and by establishing a course of higher instruction for commissioned officers.

In still another direction General Hazen showed his devotion to scientific interests, namely, by his desire to conform as thoroughly as possible to the recommendations of the International Meteorological Conferences. These recommendations, as soon as received in the printed Minutes of the Conferences, were, by General Hazen's orders, carefully examined, and instructions at once prepared calculated to introduce methods of observation and publication in conformity with the recommendations of the leading meteorologists of the world.

Among the items specially noteworthy wherein General Hazen developed new paths of activity for this service, may be especially mentioned the study of local storms: first, tornadoes, which were especially assigned to Prof. Hazen so far as a collection of general statistics is concerned, and to Prof. Mendenhall so far as concerns the electrical phenomena proper. The study of atmospheric electricity was especially authorised, in $\mathbf{1} 884$, by an order of the Secretary of War transmitting the resolutions of the International Electrical Conference held in Paris the preceding year. After full consultations with numerous electricians throughout the country, General Hazen decided that a daily map of electric potential showing lines of equi-potential similar to the iso-barometric lines, offered hopeful prospect of eventually leading to a method of predicting the formation and motion of thuriderstorms and tornadoes. But the methods of observation and the apparatus needed first to be determined upon after careful experimental work. This whole matter was, therefore, in 1885 , committed to the hands of Prof. Mendenhall.

Perhaps the most important item in internal administration, so far as it affects the permanent scientific value of the office work, was the effort heartily furthered by Gineral Hazen to improve the accuracy and international comparability of our instrumental equipment. The standards of the International Bureau of Weights and Measures were recognised by him as being the proper legal standards for this office, and every effort was made to determine the corrections needed to reduce the past as well as the current meteorological observations of the office to agree therewith.

Perhaps the generous breadth of General Hazen's views, the absence of injurious jealousies, and his confidence in the principle that the Weather Bureau would be strengthened by the widest diffusion of an intelligent appreciation of meteorology, are in nothing more clearly shown than in the earnestness with which he stimulated the formation of State weather services and encouraged the study of meteorology in every school and college. He was painfully impressed by the disastrous influence upon individuals and business of the widespread and utterly absturd predictions of the storms and weather of 
March 9, 1884, which were distributed broadcast throughout the country, and emanated from Mr. Vennor. He saw clearly that all this harm could only be prevented by increasing the intelligence of the people in scientific matters, and heartily indorsed every effort to diffuse a more correct idea as to what constituted legitimate meteorology.

Although his duties demanded the maintenance of a great central office at Washington, yet General Hazen realised that centralisation could easily be carried too far in scientific matters, and would thus react injuriously upon the work of his office. He was desirous of rapid progress in all directions, and, to secure this, welcomed every prospect of co-operation with other institutions as well as with individuals. One of his first acts was the request for co-operation on the part of the National. Academy of Science. $\mathrm{He}$ improved the opportunity to help Prof. Langley in the determination of the absorbing power of the atmosphere; he accepted Prof. King's offer to carry observers on his balloon voyages; he heartily furthered Lieut. Greely's efforts to maintain an International Polar Station, and joined with the Coast Survey in establishing a similar station under Lieut. Ray at the northern point of Alaska; he co-operated with the Bureau of Navigation in securing weather reports from the ocean; he powerfully assisted the Meteorological Society in its labours for the reformation of our complicated system of local times, the result of which was the adoption' by the country of the present simple system of standard meridians one hour apart.

Equally successful was he in his efforts to co-operate in various methods of disseminating and utilising the knowledge obtained by the Weather Bureau for the benefit of the business interests of the country. With the telegraph companies he published the daily telegraph bulletin. Through the railroad companies, he displayed the railroad train-signals visible to every farmer along the railroads. With local Boards of trade and other business interests he elaborated our system of flood warnings in the river valleys.

General Hazen was especially clear in his views as to the importance of giving personal credit to each man for his own personal work. Routine work was credited to the assistants in charge and not to the impersonal office. Having assigned a special work to the best man available, he took pains to give him the credit and make him personally responsible for its success, thus securing more enthusiasm in the work.

This notice of a few prominent features in the intense activity of General Hazen's life seems eulogistic rather than historical; but the fact is that military life rarely offers a position that requires the promotion of any special science, and still more rarely do official or military circles present an officer who so thoroughly desired, as far as allowable, to relax stringent military law and liberally interpret cumbersome official regulations, so that scientific men might successfully promote their special work.

Washington, February

C.LEVELAND ABBE

\section{SIR WALTER ELLIOT, K.C.S.I., LL.D., F.R.S.}

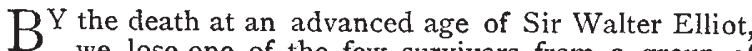
we lose one of the few survivors from a group of men who, in the second quarter of the present century, by their contributions to the zoology of British India, laid the foundations of our present knowledge. The subject of the present notice was, however, so widely known for his acquaintance with the history, coins, languages, and ancient literature of Southern India, that his zoological work might easily be overlooked.

Sir Walter Elliot was born in 1803 at Edinburgh. He was the son of Mr. James Elliot, of Wolfelee, Hawick,
Roxburghshire, and after being educated at Doncaster, and later at Haileybury, where he received a "highly distinguished" certificate, he :entered the East India Company's. Madras civil service in 1820 . In that service he held many posts of distinction. From 1822 to 1833 he was assistant to the political agent of the Southern Mahratta country, and during this period he collected the information subsequently embodied in his Catalogue of the Mammalia inhabiting the region, and also commenced the series of archæological studies, some of the first-fruits of which in 1836 were presented to the Royal Asiatic Society in the shape of a paper on Hindu inscriptions. With this paper were sent two manuscript volumes containing copies of no less than 595 sculptured records from the Southern Mahratta country and the neighibouring territory.

In 1837. he was private secretary to Lord Elphinstone, then Governor of Madras, and he was subsequently for twelve years a member of the Madras Board of Revenue. The value attached to his linguistic knowledge was shown by his being at one time Canarese translator, and at another acting Persian interpreter to the Government. From I849 to 1854 he was Commissioner for the Northern Circars. During this period he made the collection of Cetacea subsequently described by Sir $R$. Owen in the Transactions of the Zoological Society, vol. vi. Finally he was Senior Member of Council in Madras from I 854 to 1859 , when he retired from the service, and returned to pass the remainder of his life at Wolfelee, the residence of many generations of his ancestors. Almost his last official act in India was, when in charge of the Madras Government in 1858 , to take the principal part in the transfer of the Presidency from the rule of the East India Company to the direct government of the Queen. He was created a K.C.S.I. in 1866 , and became a Fellow of the Royal Society in 1878 , and he was Deputy-Lieutenant of his county.

In his retirement his attention was much given to numismatics, and despite the complete loss of his eyesight in his later years, he carried to completeness the studies commenced in his "Numismatic Gleanings on South Indian Coins," published in the Madras Fournal of Literature and Science for 1857 . He brought out in 1885, with the aid of Mr. Thomas, General Pearse, and other friends, a general work on the "Ancient and Mediæeval Coins of Southern India." Up to the very last his interest in Oriental literature remained unabated. One of his friends received a letter signed by him and clated March I, the day of his death, containing inquiries as to the forthcoming edition of a Tamil work, and suggesting that the attention of Madras native students should be bestowed upon the early dialects of their own language. During the last ten years numerous notes by Sir W. Elliot have appeared in the Indian Antiquary, the latest in the September number of last year. Largely through his efforts the Amravati sculptures, now in the British Museum, were added to the national collection, and this was but one of the valuable additions due to him. His Southern Indian coins, a very large and important series, were presented to the same institution, and his numerous zoological collections enriched the Natural History Museum.

Although his published papers on zoology give but an imperfect idea of his contributions to the science, for many of his observations were freely communicated to other naturalists, and published by them, his "Catalogue of the Species of Mammalia found in the Southern Mahratta Country," which appeared in the Madras fournal for 1842, was of unusual merit. It had the peculiar advantage that it was a list, not of museum specimens, but of the wild animals inhabiting the country, several of which, and indeed nearly all the smaller rodents, were discovered by the author. The habits of the larger animals were described from personal observation, not, as has so 